\title{
Elongate Hemlock Scale, an Exotic Scale Insect Pest of Christmas Trees and Other Conifers ${ }^{1}$
}

\author{
Adam Dale, Travis Birdsell, and Jill Sidebottom²
}

\section{Insect Origin and US Distribution}

Elongate hemlock scale, Fiorinia externa Ferris (Hemiptera: Diaspididae), is an armored scale insect native to Japan and eastern Asia (Murakami 1970). This insect was first documented in the United States in 1908 in Queens, NY, and has since spread throughout most of the eastern United States. Elongate hemlock scale was found as far south as Georgia by the late 1970s (Stimmel 1979) but has not been documented in Florida (Figure 1).

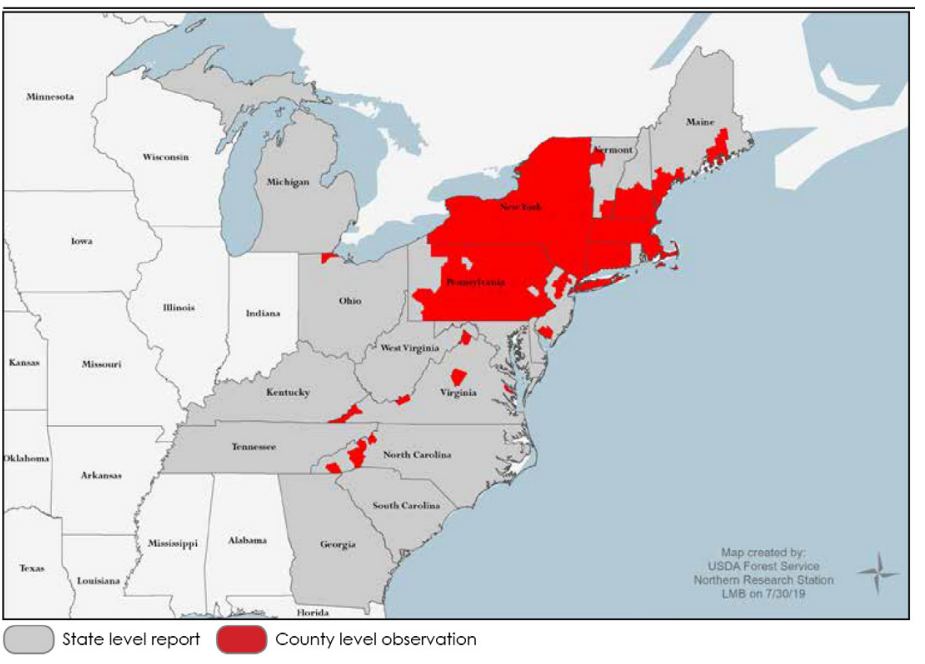

Figure 1. Elongate hemlock scale distribution in the United States. States highlighted in gray indicate a state-level report of this insect. Red coloration indicates a county-level observation. Based on data from the USDA Forest Service, updated July 30, 2019.

\section{Insect Description and Biology}

Elongate hemlock scale has a piercing-sucking mouthpart, which it uses to feed on cell contents within conifer needles. Like other armored scales, it does not feed in the vascular tissue. This insect is typically found on the underside of needles and therefore may be difficult to detect. Elongate hemlock scale undergoes one to two overlapping generations per year with more generations occurring in warmer climates (Talerico et al. 1967, Stimmel 1980). As with most other armored scales, elongate hemlock scale females undergo three life stages (egg, nymph, adult) and nymphs undergo two developmental stages (crawler and sessile nymph) before maturing into an adult. Unlike females, males go through a pre-pupal and pupal stage and then become a winged adult.

As the name implies, elongate hemlock scale is longer than it is wide. Males and females look quite different from each other. Adult females are dark brown, never develop wings, and remain underneath their armored cover throughout their life. Males are white and produce white filaments as they mature. Although the insect is on the underside of the needles, this white, dusty appearance is visible from the upper surface of the needles, making it one of the first signs that the pest is present. Adult males mature to about 1.5 mm long, develop wings, and eventually fly to mate with females. After mating, each female produces approximately 20 eggs underneath her armored cover, which hatch and

1. This document is ENY2039, one of a series of the Entomology and Nematology Department, UF/IFAS Extension. Original publication date September 2019. Visit the EDIS website at https://edis.ifas.ufl.edu for the currently supported version of this publication.

2. Adam Dale, assistant professor, turfgrass and ornamental entomology, Entomology and Nematology Department; Travis Birdsell, county Extension director and agriculture Extension agent, North Carolina Cooperative Extension; and Jill Sidebottom, area Extension specialist, Department of Forestry and Environmental Resources, North Carolina State University; UF/IFAS Extension, Gainesville, FL 32611.

The Institute of Food and Agricultural Sciences (IFAS) is an Equal Opportunity Institution authorized to provide research, educational information and other services

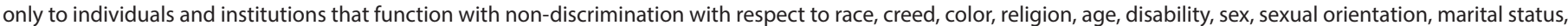

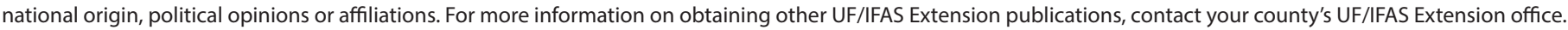
U.S. Department of Agriculture, UF/IFAS Extension Service, University of Florida, IFAS, Florida A \& M University Cooperative Extension Program, and Boards of County Commissioners Cooperating. Nick T. Place, dean for UF/IFAS Extension. 
emerge over the course of several weeks (Stimmel 1979). With careful inspection under magnification, the eggs can be seen inside the adult female scale.

The only mobile life stage and therefore the only life stage that can infest new plant material is the first instar nymph, or crawler, which is yellow. Crawlers move passively on the wind or on animals (e.g., birds) moving from plant to plant. The movement of infested plant material can also spread this pest to new areas. In the mid-Atlantic region of the United States, where this insect typically undergoes two generations, spring and fall seasons coincide with peak egg hatch and crawler emergence (Lambdin et al. 2008) though crawlers have been observed during warm periods every month of the year. The continual production of crawlers is one reason that elongate hemlock scale is so difficult to control (Talerico et al. 1967).

\section{Host Plant Species}

On the US East Coast, elongate hemlock scale primarily attacks two native forest tree species, eastern hemlock (Tsuga canadensis) and Carolina hemlock (Tsuga caroliniana). True firs (Abies spp.) and Douglas fir (Pseudotsuga menziesii) have also proven to be good hosts in commercial nursery and Christmas tree production. In addition, six other genera of conifers are reported as viable hosts, including: Juniperus, Platycladus, Cedrus, Picea, Pinus, and Taxus (Talerico et al. 1967, Stimmel 1979, Danzig and Pellizzari 1998, Tao 1999, Miller and Davidson 2005). Plants other than conifers are not affected. Hosts other than hemlock and fir typically become infested when they are growing in the vicinity of a primary host.

\section{Ecological and Economic Importance}

This insect is generally considered a pest of conifers (Miller and Davidson 1990). Infestation by elongate hemlock scale can result in chlorotic mottling of needles and needle drop, though infested hosts sometimes exhibit very few symptoms, even when heavily infested for several years. Natural enemies, primarily a parasitic wasp, Encarsia citrina, which is a common parasite of armored scales, often keep elongate hemlock scale below damaging levels. Broad-spectrum insecticide applications may reduce parasitism and facilitate scale outbreaks. Increased host stress (e.g., drought) has also been associated with increased elongate hemlock scale abundance and damage. Under these adverse conditions, needle drop increases, resulting in branch dieback and possible death of the host tree (McClure 1977, Kosztarab 1996).
Elongate hemlock scale is also a key pest of Fraser fir (Abies fraseri) Christmas trees, a conifer native to the Appalachian region of the United States that is grown in several states for Christmas tree production (Stimmel 1979). Beginning in the 1980s, elongate hemlock scale became an economic pest of Fraser fir on Christmas tree farms in Pennsylvania and was first observed on North Carolina Christmas tree farms in 1993. Although Fraser fir infested with elongate hemlock scale often show few outward symptoms, they do create an aesthetic and regulatory challenge for growers trying to ship them into states without the insect. North Carolina Christmas tree producers indicate that problems with elongate hemlock scale have increased from just $0.3 \%$ of growers in 2000, to $2.3 \%$ in 2006, and 53\% in 2013 (Sidebottom personal communication). For more information on elongate hemlock scale in North Carolina Christmas trees, including control measures, see https://content.ces. ncsu.edu/elongate-hemlock-scale.

From 2012-2016, approximately 17\% (or 700,000 trees) of North Carolina's annual cut Christmas tree harvest were shipped annually into Florida's retail market for sale (USDA 2019, NCDACS). Since elongate hemlock scale is not established in Florida, its detection has warranted regulatory action. When frequent regulatory action prohibits the movement of Christmas trees into Florida, it inflicts a major economic burden on North Carolina growers and Florida retail outlets.

\section{Risk to Florida Conifers}

Though the primary hosts, hemlocks and firs, do not occur in Florida, there are concerns that elongate hemlock scale coming into the region on cut Christmas trees may disperse and establish on conifers that do occur in Florida. Of specific interest are two endangered species, Florida torreya (Torreya taxiflora) and Florida yew (Taxus floridana), which are native to a small region in northwestern Florida. Also of concern are Florida forestry species, Florida Christmas tree species, and species used for ornamental plantings in Florida. Based on the host species reported in the literature, University of Florida and North Carolina State University researchers selected sixteen conifer species of importance to Florida and evaluated them for susceptibility to elongate hemlock scale.

Researchers found that on average, a 6-inch Fraser fir twig heavily infested with live adult female elongate hemlock scale released 685 crawlers, which emerged over the course of 40 days. Peak crawler emergence occurred 2-3 weeks after Fraser fir twigs were removed from the tree. It is important to note that this magnitude of emergence 
occurred from freshly cut, heavily infested plant material and may not represent emergence numbers from harvested and distributed Christmas trees. Although crawler presence periodically coincides with Christmas tree shipments, and despite these results, we still have a poor understanding of the timing, duration, and magnitude of true crawler emergence, especially after a Fraser fir tree is harvested, stored on-farm under varying conditions (i.e. under natural shade vs. refrigeration), loaded onto a truck, and shipped across the region.

During the study, researchers inundated 25-30 of each tree species with several hundred elongate hemlock scale crawlers over the course of 80 days. Scale insect populations were then allowed to develop for 50 weeks and three insect generations. After 50 weeks, the number of reproductive females and live scales per plant were counted. The presence of a reproductive female indicates that a host plant successfully supported the development of an elongate hemlock scale crawler to an adult female that mated and produced viable offspring.

Researchers found that four of the sixteen evaluated hosts were at moderate to high risk of elongate hemlock scale infestation. Importantly, none of the moderate- to high-risk hosts are native to or commonly used in Florida. Six of the sixteen evaluated plant species were found to be at low or extremely low risk of infestation, and six of the sixteen evaluated species were confirmed as not hosts. The endangered species of concern, Florida torreya and Florida yew, are at extremely low risk and not a host, respectively. Table 1 below summarizes the findings of this work.

Despite the findings of this research, elongate hemlock scale remains an exotic insect that is not established in the state of Florida. Therefore, regulatory action to limit the likelihood of elongate hemlock scale dispersal and establishment into Florida is still warranted.

\section{References}

Danzig, E. M., and G. Pellizzari. 1998. Diaspididae. Catalogue of Palaearctic Coccoidea. Plant Protections Institute, Hungarian Academy of Sciences Budapest, Hungary 526 pp.

Kosztarab, M. P. 1996. Scale insects of Northeastern North America. Identification, biology, and distribution. Virginia Museum of Natural History. Martinsburg, VA 650 pp.

Lambdin, P. L., J. Grant, and R. C. Reardon. 2008. Density and distribution of the elongate hemlock scale on eastern hemlock in the southern Appalachians. Proceedings of the XI International Symposium on Scale Insect Studies, Oeiras, Portugal, 24-27 September 2007. ISA Press Lisbon, Portugal $322 \mathrm{pp}$.

McClure, M. S., and M. B. Fe. 1977. Fiorinia externa and Tsugaspidiotus tsugae (Homoptera: Diaspididae): distribution, abundance, and new hosts of two destructive scale insects of eastern hemlock in Connecticut. Environmental Entomology 6: 807-811.

Miller, D. R., and J. A. Davidson. 1990. A list of the armored scale insect pests. Armored Scale Insects, Their Biology, Natural Enemies and Control [Series title: World Crop Pests, Vol. 4B]

Miller, D. R., and J. A. Davidson. 2005. Armored scale insect pests of tree and shrubs. Cornell University Press, Ithaca, NY $442 \mathrm{pp}$.

Murakami, Y. 1970. A review of the biology and ecology of Diaspine scales in Japan (Homoptera, Coccoidea). Mushi 43: 65-114.

Stimmel, J. F. 1979. Elongate hemlock scale, Fiorinia externa Ferris Homoptera: Diaspididae. Pennsylvania Department of Agriculture Bureau of Plant Industry. Entomology Circular No. 36. Vol. 5, No.1.

Stimmel, J. F. 1980. Seasonal history and occurrence of Fiorinia externa Ferris in Pennsylvania (Homoptera: Diaspididae). Proceedings of the Entomological Society of Washington 82: 700-706.

Talerico, R. L., C. W. McComb, and W. T. Garrett. 1967. Fiorinia externa Ferris, a scale insect of hemlock. United States Department of Agriculture, Forest Service, Forest Pest Leaflet, 107:1-4.

Tao, C. C. C. 1999. List of Coccoidea (Homoptera) of China. Special publication (Taiwan Agricultural Research Institute) No. 78: 1-175.

USDA Forest Service, Northern Research Station and Forest Health Protection. "Alien Forest Pest Explorer - species map." Database last updated 30 July 2019. https://www.nrs. fs.fed.us/tools/afpe/maps/

USDA NASS. 2019. 2017 United States Census of Agriculture. Volume 1 Part 51. AC-17-A-51. https://www. nass.usda.gov/Publications/AgCensus/2017/Full_Report/ Volume_1,_Chapter_1_US/usv1.pdf 


\section{PHOTO GUIDE FOR ELONGATE HEMLOCK SCALE}

\section{Symptoms:}

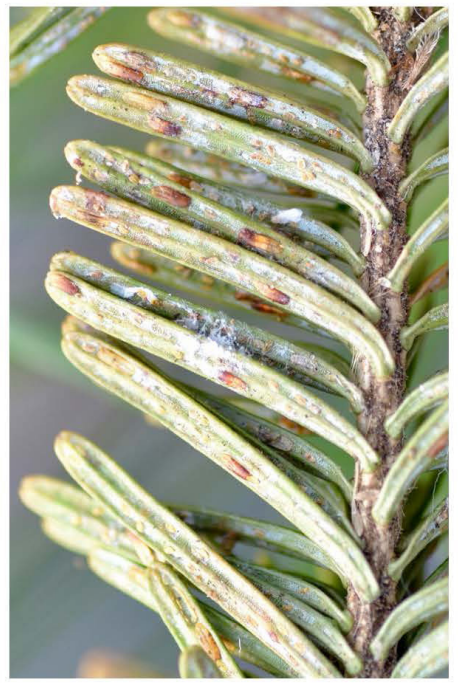

Heavily infested underside of Fraser fir

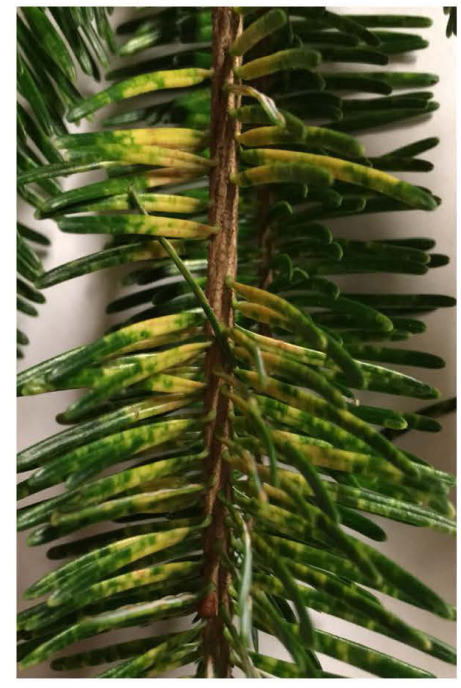

Chlorotic damage on top-side of Fraser fir

\section{Life cycle:}

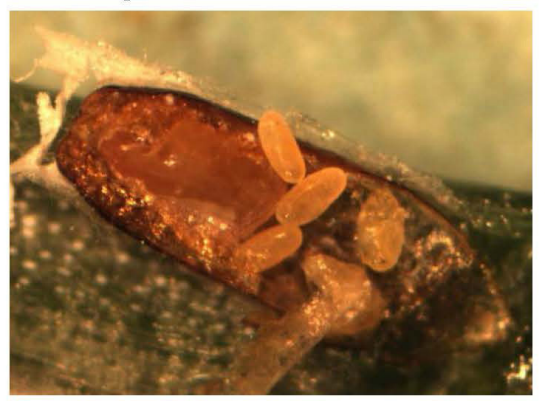

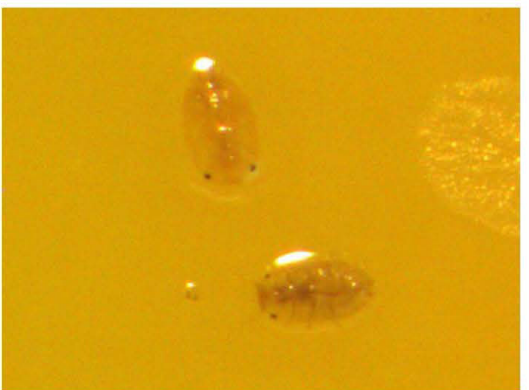

First instar nymphs (crawlers)

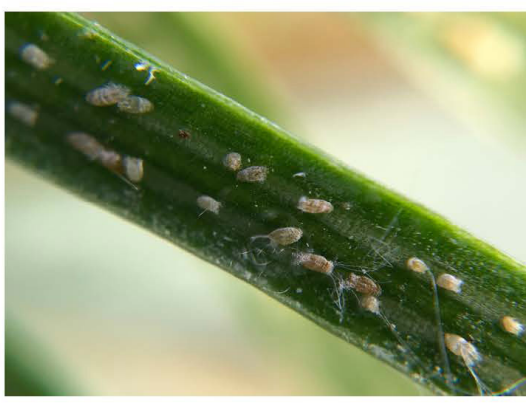

Second instar nymphs

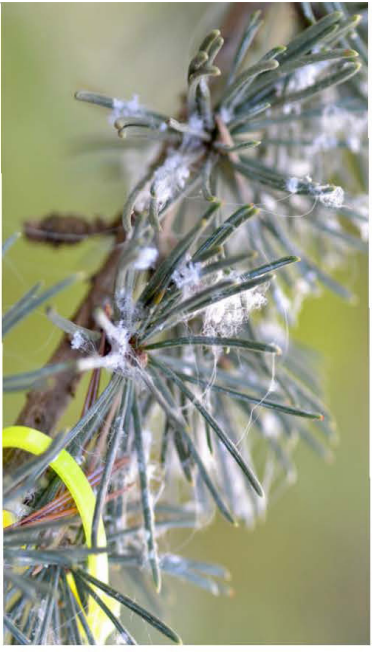

Maturing males

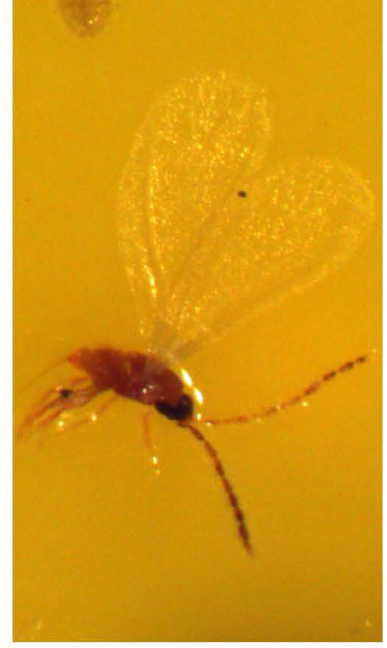

Adult male

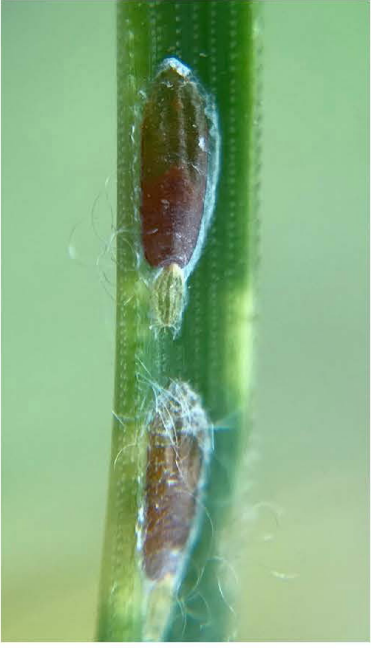

Adult females

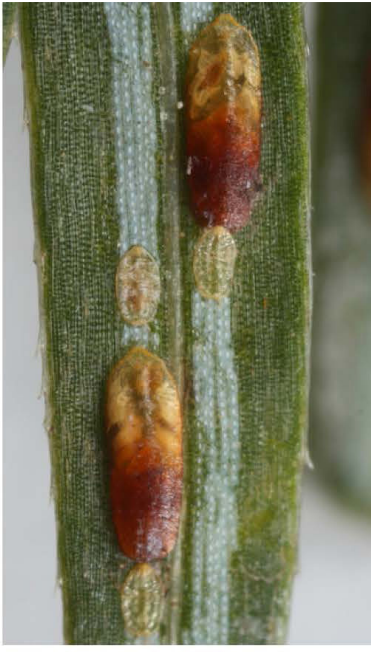

Gravid adult females

Figure 2. Photo guide for elongated hemlock scale.

Credits: Heavily infested underside of Fraser fir_Adam Dale, UF/IFAS; Chlorotic damage on top-side of Fraser fir-Jill Sidebottom, NC State University; Eggs from within an adult female—Jill Sidebottom, NC State University; First instar nymphs (crawlers)—Jill Sidebottom, NC State University; Second instar nymphs—Adam Dale, UF/IFAS; Maturing males—Adam Dale, UF/IFAS; Adult male—Jill Sidebottom, NC State University; Adult females-Adam Dale, UF/IFAS; Gravid adult females-Charley Eiseman, www.charleyeiseman.com 


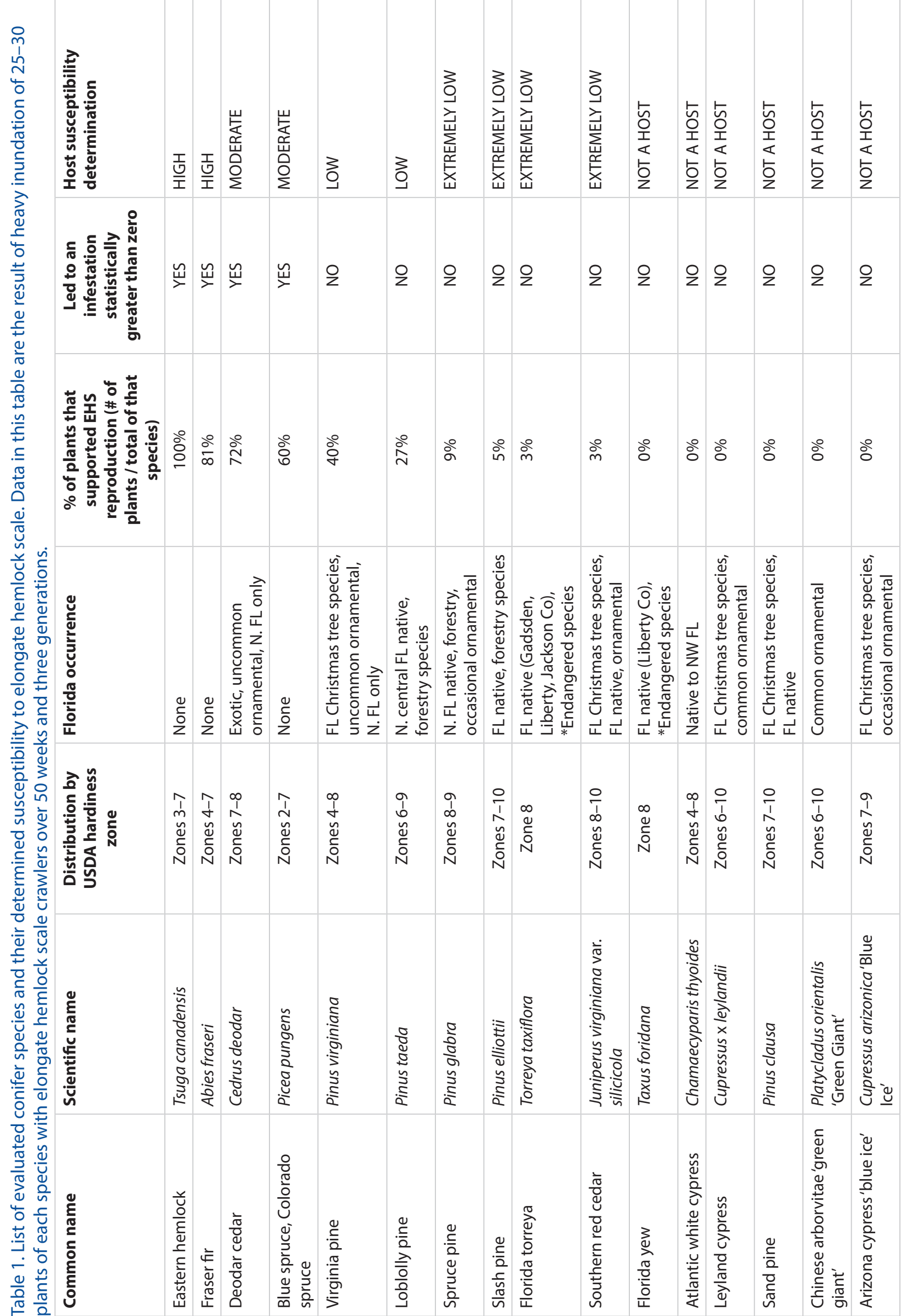

